\title{
An Introduction on the Role of Organization Capital for the Enterprise's Endogenous Growth
}

\author{
Hui Wang \\ School of Economics and Management, Southwest Jiaotong University, Chengdu, China \\ Email: tmlbt1978@163.com
}

Received 18 May 2016; accepted 18 June 2016; published 21 June 2016

Copyright (C) 2016 by author and Scientific Research Publishing Inc. This work is licensed under the Creative Commons Attribution International License (CC BY). http://creativecommons.org/licenses/by/4.0/ c) (i) Open Access

\begin{abstract}
The value of enterprise substantially depends on its ability of value creation in the future. Enterprise value creation relies on the external resources, but its own endogenous ability also becomes more and more important. This paper utilizes the concept of organization capital to survey enterprise' core competitive ability and the growth of the enterprise value, which provides a new view for analysis of the enterprise endogenous growth.
\end{abstract}

\section{Keywords}

\section{Organization Capital, Enterprise Value, Core Competency}

\section{Introduction}

The value of an enterprise benefits from its core competitiveness. The core competitive ability is unique for an enterprise. It is a set of enterprise behavior including such as strategic management, operational control and investment development, which aims to be different from other competitors. Therefore, an enterprise' core competitive ability not only has the characteristics of value creation, but also is a reflection of a heterogeneous enterprise. The organization capital is also a capital input and it means that the enterprise organization integrates every kind of production factors to maximize enterprise profits based on enterprise's own characteristic. The value of an enterprise depends on its core competitive ability, and the core competitive ability belongs to a kind of intangible assets. Therefore, the analysis of relation between enterprise organization capital and the core competitive ability will help to analyze and explain the inner motive power of increasing enterprise value and be beneficial to evaluating the enterprise value. 


\section{A Literature Review on Organization Capital}

The essence of organization capital is that an enterprise take its heterogeneity including the intangible assets such as the organizational structure, the governance mechanism, the management practice, as well as the enterprise culture and so on as a kind of capital goods, then by capitalizing the output made by these intangible assets an enterprise' value will be measured.

Adam Smith was the first one to notice the influence of the enterprise organization on the output. He believed that adjusting the enterprise' production organization could greatly improve labor productivity and increase the output. Similarly, Taylor's scientific management practice proved that the enterprise internal management greatly influence on the output efficiency. But, for the mechanism of the enterprise organization how to influence on the output and how to measure and assess the value of the enterprise organization capital, they did not elaborate.

Prescott and Visscher (1980) defined the good coordination between the enterprise employees and their corresponding tasks as the organization capitals, and believed this kind of capitals was the enterprise' unique human capital [1]. Kaplan and Norton (2004) took the enterprise' own characteristics such as enterprise culture, leadership, internal target consistency, team share as the organization capital when they analyzed the enterprise strategic and thought the degree of readiness of organization capital would seriously affect the enterprise strategy [2]. Lev and Radhakrishnan (2005) took the internal enterprise behaviors which were different from competitors and were not easy to be copied by the competitors as the organization capital [3]. These behaviors included the technical, the commercial design, the process and the operation practice. Liu Chao (2008) defined two kinds of capital, one was the process capital and the other was innovation capital. He thought the process capital was the organizational environment, atmosphere, or mechanism where organizational members were able to give play to their own knowledge and ability [4]. The innovation capital meant the methods, procedures and ability by which production factors were combined and innovated, such as the intellectual property and the trade secrets. The enterprise organization capital consists of the two types of capital. Di Qiang and Guo Junhua (2010) argued that the enterprise organization capital was a phenomenon that the enterprise transformed its members' knowledge, skills and experience into organizational resources or assets to create profits [5]. Eisfeldt and Papanikolaouz (2013) took the key talent who exert important influence on the company's performance as the organization capital [6]. Zhou Yan and Tong Xun (2013) suggested that the organization capital was enterprise's unique knowledge and skills for making use of its own resource which was gradually formed with the development of the enterprise. Enterprises can use the organization capital to further optimize the allocation and employment of resources [7].

Due to the importance of organizational capital, measuring or evaluating the organization capital has also been the attention of many scholars. Atkeson and Kehoe (2005) deal the organization capital with an input and measured the organization capital's contribution to the output by structural equation in the study of America's manufacturing output [8]. Lev and Radhakrishnan (2005), Lev and Zhang (2009) estimated the contribution value of enterprise organization capital by using the production function and the enterprise's financial data [9]-[11]. Xu Zhiwei and Wu Huabin (2012) made a study on factors influencing China's macroeconomic volatility, by using a Bayesian method based on the system model and from the perspective of organization capital. The results showed that the model containing organizational capital can better explain China's macroeconomic data than the model without the organization capital [12]. Eisfeldt and Papanikolaouz (2013) argued that as a key human capital, the organization capital will affect the income distribution of shareholders and managers. Their empirical results showed that the higher was the organization capital, the risk faced by shareholders was higher [13].

Much research on organization capital agreed that the concept of organization capital had a good explanation to the output contribution of organization. Especially in the research on enterprise endogenous growth, organization capital can better explain the enterprise's competitive advantage and growth. However, because organization capital is a new and comprehensive concept involved different disciplines such as management, economics and accounting, which result in the definition of organization capital still are not be unified and easy to confuse with some concepts such as human capital, intangible assets, enterprise management, enterprise culture. Therefore, it is necessary to differentiate these concepts.

1) Organizational capital and human capital

Shao Lin (2014) pointed out that the individual human capital is the knowledge, skills and health condensed 
on labor [14]. Fu Yu (2014) pointed out that human capital was a stock of intellectual capital and relationship capital, and if the human capital wanted to create value, there must be a suitable environment matching with the human capital [15]. Ma Hongqi and Wang (2014) also thought that human capital dependent on not only the personal itself but also the economic system and environment [16].

Enterprise although obtained the right to use the human capital through pay, but it did not mean that the enterprise can fully achieve the greatest value created by human capital. Namely, the enterprise paid wages, but employees not necessarily tried their best to work.

Zhou Qiren (1996) and Zhang Gang (2000) both believed that the property rights of human capital belong to the corresponding employee and this capital created value under appropriate environment. The ability of stimulating human capital was exactly organization capital [17] [18].

2) Organizational capital and intangible assets

Xiang Xianhu and Liu Tian (2014) argued that the concept of intangible assets belonged to accounting and finance and intangible assets included human capital and Organization capital. That is to say, the organization capital is part of intangible assets [19].

3) Organization capital and the enterprise culture

Yi Liang (2012) argued that the enterprise culture was essentially a kind of unwritten and established rules and practices rooted in enterprise organization, which reflected the characteristics of the organization [20].

Xiang Xianhu and Hu Shaohua (2009) points out that the organization capital included processes organization capital such as governance institution, organization system, as well as culture class organization capital such as values, organizational routines, cultural atmosphere [21]. The ability of effectively matching employees with their tasks is exactly the organization capital. Therefore, the enterprise culture is not the same as the organizational capital, organization capital include the enterprise culture, but the enterprise culture is not the same as organizational capital.

4) Organization capital and corporate governance

Eisfeldt and Papanikolaouz (2013) considered the organization capital as a special human capital and pointed out that the mechanism of corporate governance was substantially a kind of special enterprise's organizational structure and institutional arrangement which reflected the heterogeneity of the enterprise. Therefore, corporate governance is part of the organizational capital [22].

Comprehensively, Capital is a collection of intangible assets including human capital, governance institution, enterprise culture etc. For different enterprise organization, the composition of the elements in this collection is different. The organization capital can comprehensively reflect the contribution of intangible assets to the enterprise.

\section{The Influence of Organization Capital on Enterprise Growth}

\subsection{Building Enterprise Core Competitive Ability}

According to Barney (1991), when an enterprise can implement the strategy of creating value for the enterprise which other existing and potential competitors did not adopt, said the company has a competitive advantage. And if the strategy could not be adopted and imitated by other competitors, the enterprise had sustainable competitive advantage and core competitive ability.

The role of enterprise core competitive ability is in the market competition to obtain more economic profits than the competition, and contribute to the continued survival and development of the enterprise. To achieve this, the enterprise should have the following three advantages. One is the advantage of efficiency. Input and output is the essence of business activity. High efficiency means the output is maximized under the given input, or the cost is minimized under the given output. This advantage will ensure enterprise continued survival and development. The second is the advantage of innovation. With the development of science and technology, a temporary competitive advantage is fragile. Therefore, if an enterprise wants to maintain the sustainability of competitive advantage, innovation is its inevitable choice. The last one is the advantage of integration. According to Ronald H. Coase (1936), an enterprise is a collection of a series of contracts. Through contracts, the enterprises have access to resources and make use of them, but for different enterprise, its resource acquisition ability and use is different, which reflect every enterprise are different in the resources integration ability. Generally, the enterprise which has the competitive advantage often continuously improve its organization structure, system design and operation scheduling to enhance the efficiency and the innovation ability.

The above analysis showed that the heterogeneity of enterprise determines the difference in core competitive 
ability and the heterogeneity of enterprise depends on the characteristics of enterprise's organization characteristics. As a collection of enterprise's own comprehensive characteristics, the organization capital reflects both enterprise's resource access ability and efficiency of using resources. At the same time, because of organization capital is belonging to different companies, it has the characteristics of exclusiveness. Different organization capital just also reflects the core competitive ability of exclusivity. Therefore, as a result of organization capital is closely related to the management level, the profitability of organization capital is the source of core competitiveness for modern enterprise.

\subsection{Promoting the Enterprise Growth}

The American economist Penrose (1959) proposed the concept of enterprise based on enterprise resources. He argued that the growth of the enterprise value was a dynamic process that the enterprise's internal resources and knowledge kept increasing with the expansion of the enterprise scale [23]. The dynamic process is shown in Figure 1.

Although Penrose's model of enterprise growth did not adopt the concept of organizational capital, the concepts adopted such as management ability, resource utilization, knowledge etc. belongs to the category of organization capital. Therefore, it can be used in deep analysis on an enterprise's value growth path based on organizational capital. An enterprise will accumulate knowledge and experience in its long-term business practice, and the knowledge and experience will improve the ability of employees and increase labor productivity by the more effective use of stock resources (see cycle 1). At the same time, the knowledge and experience also will improve the management level and constantly improve enterprise operation efficiency (see cycle 2). As companies grow larger, the management complexity also will increase and the limited managers energy will restrict the growth of enterprises (see cycle 3).

On the whole, the enterprise growth and its value increase is exactly a process involving the accumulation or increase of organization capital such as knowledge, experience, management ability etc. It is the organization capital that makes the enterprise is more effective in the allocation of resources and adopts suitable methods to coordinate production activities through specialization. Meanwhile, highly specialized division of labor will promote the accumulation of organization capital, which will boost output and improve the value of the company.

\section{Conclusion}

An enterprise must have its competitive advantage in market competition and the competitive advantage relative to other competitors is the enterprise core competitive ability. Enterprise core competitive ability comprehensively reflects the characteristics of an enterprise organization. The concept of organization capital can evaluate

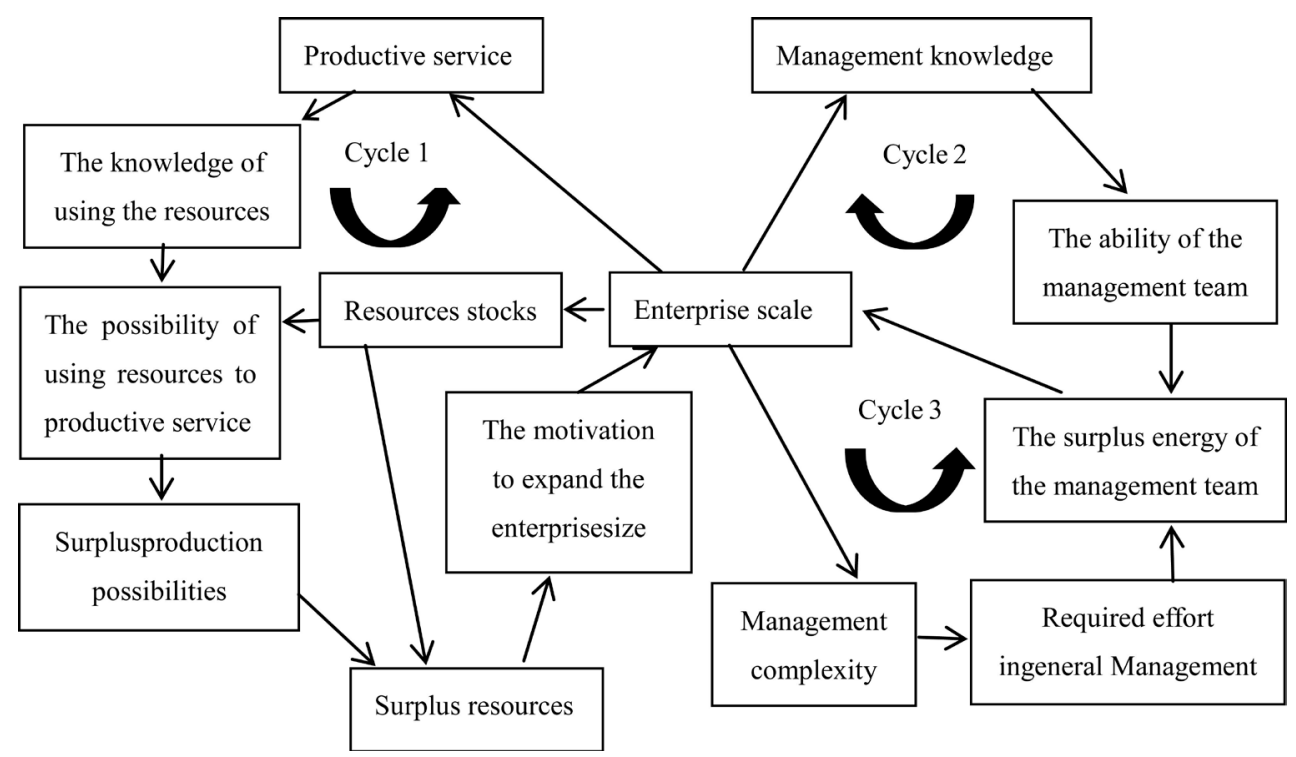

Figure 1. Penrose's model of enterprise growth. 
the characteristic of enterprise organization and enterprise's value creation. Therefore, by using the concept of organization capital, we can further comprehend an enterprise's core competitive ability and value creation process. For the purpose of enhancing the core competitive ability and improving value creation, the enterprise should attach great importance to its organization capital.

\section{References}

[1] Prescott, E.C. and Visscher, M. (1980) Organization Capital. The Journal of Political Economy, 88, 446-461. http://dx.doi.org/10.1086/260879

[2] Kaplan, R.S. and Norton, D.P. (2004) The Strategy Map: Guide to Aligning Intangible Assets. Strategy \& Leadership, 32, 10-17. http://dx.doi.org/10.1108/10878570410699825

[3] Lev, B. and Radhakrishnan, S. (2005) The Valuation of Organization Capital, in Measuring Capital in the New Economy. University of Chicago Press, Chicago. http://dx.doi.org/10.7208/chicago/9780226116174.003.0004

[4] Liu, C. (2008) Research on Enterprise Capital Management Ability. Dalian University of Technology, Dalian, 22-25.

[5] Di, Q. and Guo, J.H. (2010) Organizational Capital and Organizational Performance. Shanghai Jiao Tong University Press, Shanghai, 89-96.

[6] Eisfeldt, A.L. and Papanikolaou, D. (2013) Organization Capital and the Cross-Section of Expected Returns. The Journal of Finance, 68, 1365-1406. http://dx.doi.org/10.1111/jofi.12034

[7] Zhou, Y. and Tong, X. (2013) Analysis of the Inert Tendency of Enterprise Organization Capital. Modern Management Science, No. 5, 68-72.

[8] Atkeson, A. and Kehoe, P.J. (2005) Modeling and Measuring Organization Capital. Journal of Political Economy, 113, 1026-1053. http://dx.doi.org/10.1086/431289

[9] Lev, B., Radhakrishnan, S. and Zhang, W. (2009) Organization Capital. Abacus, 45, 275-298. http://dx.doi.org/10.1111/j.1467-6281.2009.00289.x

[10] Xu, Z.W. and Wu, H.B. (2012) The Impact of Enterprise Organization Capital on China's Macroeconomic Fluctuations. Management World, No. 3, 23-33.

[11] Shao, L. (2014) Research on Human Capital’s Influence on China’s Economic Growth. Jilin University, Changchun, 56-62.

[12] Fu, Y. (2014) Research on Contribution of Structure of Human Capital to Economic Growth. Jilin University, Changchun, 23-35.

[13] Ma, H.Q. and Wang, R. (2014) The New Understanding of Human Capital Formation Theory. Economists, No. 12, 3341.

[14] Zhang, G. (2000) From Human Capital to Organizational Capital: An Analysis of “Economic Man” Hypothesis. Communication Dialectics of Nature, No. 2, 42-50.

[15] Zhou, Q.R. (1996) The Enterprise in The Market: A Special Contracts of Human Capital and Non-Human Capital. Economic Research, No. 9, 71-79.

[16] Liang, X.J. (2006) The Embodiment of Competitiveness on Enterprise Culture in Continued Operation. The Foreign Economic and Trade University, Beijing, 45-48.

[17] Ai, L. (2012) Research on Enterprise Culture Construction Research. Tianjin University, Tianjin, 78-82.

[18] Xiang, X.H. and Hu, S.H. (2009) Organizational Capital and the Nature of the Enterprise. Contemporary Finance, No. 6, 66-70.

[19] Bai, C.E. (2005) The Empirical Study on China’s Listed Company Governance Structure. Economic Research, No. 2, 81-91.

[20] Yi, Z.H., Jiang, F.X. and Qin, Y.H. (2010) Product Market Competition, Corporate Governance and Disclosure Quality. Management World, No. 1, 133-141.

[21] Barney, J. (1991) Firm Resources and Sustained Competitive Advantage. Journal of Management, 17, 99-120. http://dx.doi.org/10.1177/014920639101700108

[22] Penrose (2007) Firm Growth Theory. Shanghai Sanlian Bookstore, Shanghai, 79-89.

[23] Xia, Y.N. and Zhao, S. (2015) Industrial 4.0: What Is Happening in The Future. Mechanical Industry Press, Beijing, $13-20$. 


\section{Submit or recommend next manuscript to SCIRP and we will provide best service for you:}

Accepting pre-submission inquiries through Email, Facebook, Linkedin, Twitter, etc A wide selection of journals (inclusive of 9 subjects, more than 200 journals)

Providing a 24-hour high-quality service

User-friendly online submission system

Fair and swift peer-review system

Efficient typesetting and proofreading procedure

Display of the result of downloads and visits, as well as the number of cited articles

Maximum dissemination of your research work

Submit your manuscript at: http://papersubmission.scirp.org/ 